Discussion Paper No. 08-044

\title{
Noncognitive Skills, Internet Use and Educational Dropout
}

Katja Coneus, Johannes Gernandt, and Marianne Saam

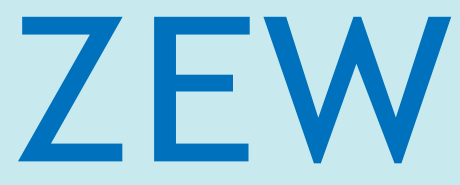

Zentrum für Europäische Wirtschaftsforschung $\mathrm{GmbH}$

Centre for European

Economic Research 
Discussion Paper No. 08-044

\title{
Noncognitive Skills, Internet Use and Educational Dropout
}

\author{
Katja Coneus, Johannes Gernandt, \\ and Marianne Saam
}

Download this ZEW Discussion Paper from our ftp server:

ftp://ftp.zew.de/pub/zew-docs/dp/dp08044.pdf

Die Discussion Papers dienen einer möglichst schnellen Verbreitung von neueren Forschungsarbeiten des ZEW. Die Beiträge liegen in alleiniger Verantwortung der Autoren und stellen nicht notwendigerweise die Meinung des ZEW dar.

Discussion Papers are intended to make results of ZEW research promptly available to other economists in order to encourage discussion and suggestions for revisions. The authors are solely responsible for the contents which do not necessarily represent the opinion of the ZEW. 
In this paper we study the determinants and labor market effects of dropping out of the educational system. In doing so we pay particular attention to factors that matter in face of increasingly complex job requirements. The two key factors we consider are noncognitive skills and Internet use. Dropouts are defined as individuals who have not completed secondary school or vocational training and who are not currently in education. The analysis is based on data from the German Socio-Economic Panel for the years 2000 to 2006.

First, we study the determinants of dropout using a sample of 16 to 22-year-olds. We find that both, noncognitive skills and Internet availability at home, reduce the probability to be a dropout. The effects remain significant if different family backgrounds are taken into account. Internet availability may reflect the benefits of Internet as an educational technology, but also a part of parents' attitudes and skills that are to some degree independent of their formal education and their income. Introducing a psychological measure as well as information on extracurricular activities (sports, music, being a class representative) to evaluate the influence of noncognitive skills, we find that the factors that reduce the dropout probability differ between women and men.

In the second part, the labor market outcomes of dropouts and non-dropouts are analyzed. At equal educational levels, those with higher noncognitive skills are less likely to be unemployed. We then look at the wage gap between dropouts and medium-skilled workers. Considering individuals in equal occupational groups, at equal levels of noncognitive skills and equal Internet use status, the wage gap between dropouts and medium-skilled workers vanishes for men. For women, the gap amounts to four percent. Finally, it is examined whether dropouts earn a higher or a lower wage premium from high noncognitive skills or from using Internet at work. We do not find any effect that is significantly different from the effect for the whole working population. 
In dieser Untersuchung der Determinanten und Effekte eines Bildungsabbruchs schenken wir solchen Faktoren besondere Beachtung, die angesichts zunehmend komplexer Anforderungen in der Arbeitswelt bedeutsam sind. Als zwei Schlüsselfaktoren betrachten wir nicht-kognitive Fähigkeiten und Internetnutzung. Bildungsabbrecher definieren wir als Personen ohne Schuloder Ausbildungsabschluss, die sich auch nicht gerade in Ausbildung befinden. Die Analyse basiert auf Daten des Sozioökonomischen Panels für die Jahre 2000 bis 2006.

Zuerst untersuchen wir die Determinanten des Bildungsabbruchs mit einer Stichprobe von 16 bis 22- Jährigen. Es zeigt sich, dass sowohl nicht-kognitive Fähigkeiten als auch die Verfügbarkeit von Internet im Haushalt die Wahrscheinlichkeit, Bildungsabbrecher zu sein, reduzieren. Die Effekte bleiben signifikant, wenn verschiedene familiäre Hintergründe berücksichtigt werden. Die Verfügbarkeit von Internet kann den Nutzen von Internet als Bildungstechnologie widerspiegeln aber auch Einstellungen und Fähigkeiten der Eltern, die in gewissem Grade unabhängig von ihrem formalen Bildungsniveau und Einkommen sind. Um den Einfluss nicht-kognitiver Fähigkeiten zu bewerten, führen wir sowohl ein psychologisches Maß nicht-kognitiver Fähigkeiten als auch Informationen über außerunterrichtliche Aktivitäten der Jugendlichen (Sport, Musik, Klassensprecherfunktion) in die Analyse ein. Wir finden heraus, dass die Faktoren, die die Bildungsabbruchswahrscheinlichkeit reduzieren, sich für Frauen und Männer unterscheiden.

Im zweiten Teil werden die Arbeitsmarkterfolge von Bildungsabbrechern und anderen Beschäftigten untersucht. Bei gleichem Bildungsniveau haben Personen mit höheren nichtkognitiven Fähigkeiten eine geringere Wahrscheinlichkeit, arbeitslos zu sein. Anschließend betrachten wir den Lohnabstand zwischen Bildungsabbrechern und Beschäftigten mit mittlerer Qualifikation. Bei gleicher Berufsgruppe, gleichen nicht-kognitiven Fähigkeiten und gleichem Internetnutzungsstatus verschwindet dieser Lohnabstand für Männer. Für Frauen beträgt er vier Prozent. Schließlich wird überprüft, ob Bildungsabbrecher eine höhere oder niedrigere Lohnprämie für nicht-kognitive Fähigkeiten und für berufliche Internetnutzung erhalten. Wir finden dabei keinen Effekt, der sich von dem für die Gesamtheit der Beschäftigten unterscheidet. 


\title{
Noncognitive Skills, Internet Use and Educational Dropout
}

\author{
Katja Coneus*, Johannes Gernandt, ${ }^{\dagger}$ Marianne Saam ${ }^{\ddagger}$
}

June 20, 2008

\begin{abstract}
Using data from the German Socio-Economic Panel for the years 2000 to 2006 we analyze the determinants and labor market effects of educational dropout. In addition to classical variables like family background and occupation, we examine noncognitive skills and Internet use. Noncognitive skills and Internet availability at home are negatively associated with the probability of becoming an educational dropout. The wage gap between dropouts and those with completed school and professional education vanishes for males once we control for additional characteristics such as occupations, professional Internet use and noncognitive skills. For females it is reduced to four percent.
\end{abstract}

Keywords: education, unemployment, wages, noncognitive skills, computer use JEL-classification: I21, J31, O30

Acknowledgements: We would like to thank Irene Bertschek, Kathrin Göggel, Andrea Mühlenweg, Friedhelm Pfeiffer and seminar participants at ZEW for helpful discussions. We also thank Jan Huntgeburth and Christiane Linder for valuable research assistance. Katja Coneus and Johannes Gernandt thank the Leibniz Association, Bonn, for support in the research network "Noncognitive Skills: Acquisition and Economic Consequences". All remaining errors are ours.

${ }^{*}$ Centre for European Economic Research (ZEW), e-mail: coneus@zew.de.

${ }^{\dagger}$ Centre for European Economic Research (ZEW), e-mail: gernandt@zew.de.

${ }^{\ddagger}$ Corresponding author: Centre for European Economic Research (ZEW), P.O. Box 1034 43, D-68034 Mannheim, Germany, tel.: +49-621-1235-285, e-mail: saam@zew.de. 


\section{Introduction}

The successful completion of secondary education and the subsequent entrance into apprenticeship has long been the privileged way of access to the labor market for German workers without advanced general education. At the same time, Germany's strong industrial sector also offered employment and on-the-job training for school leavers without a vocational degree. Over the last two decades, there has been a growing concern about young people that drop out of the system of secondary and vocational education and their labor market perspectives. The rising difficulties of dropouts on the labor market become evident when looking at the evolution of unemployment rates. Since the 1970ies, the gap between the unemployment rate for the whole population and for those without a vocational degree has risen from 2 to 15 percentage points. Most of the drift occurred before German reunification (see Figure (1)).

Reasons for educational dropout and its increasingly severe consequences can be sought on the supply and the demand side of the labor market for low- and mediumskilled workers. In light of the results of the PISA study on educational achievement of 15-year-old students, the public discussion has focused on insufficient cognitive skills of school leavers who want to enter an apprenticeship.

On the demand-side, skill-biased technological change, especially the spread of information and communication technologies (ICT), is considered to reduce the demand for low- and medium-skilled workers (Autor, Levy and Murnane, 2003). But changing requirements operate also within occupations that are not filled with high-skilled workers (Spitz-Oener, 2006). A shift to nonroutine tasks rises the requirement of abilities to master complex work situations. In this context, noncognitive skills such as self-confidence and self-control play an important role (Heckman and Rubinstein, 2001; Borghans, Duckworth, Heckman and ter Weel, 2008). The labor market success of educational dropouts can be expected to depend on the extent to which they can match these requirements in spite of lacking formal qualifications. Complex jobs more frequently involve the use of ICT such as personal computers and Internet. These technologies also play an increasingly important role in education where their benefits are, however, to some extent contested by statistical evidence. The purpose of the paper is to analyze the determinants and the effects of educational dropout paying particular attention to noncognitive skills and Internet use 
Figure 1: The development of the unemployment rate in Germany

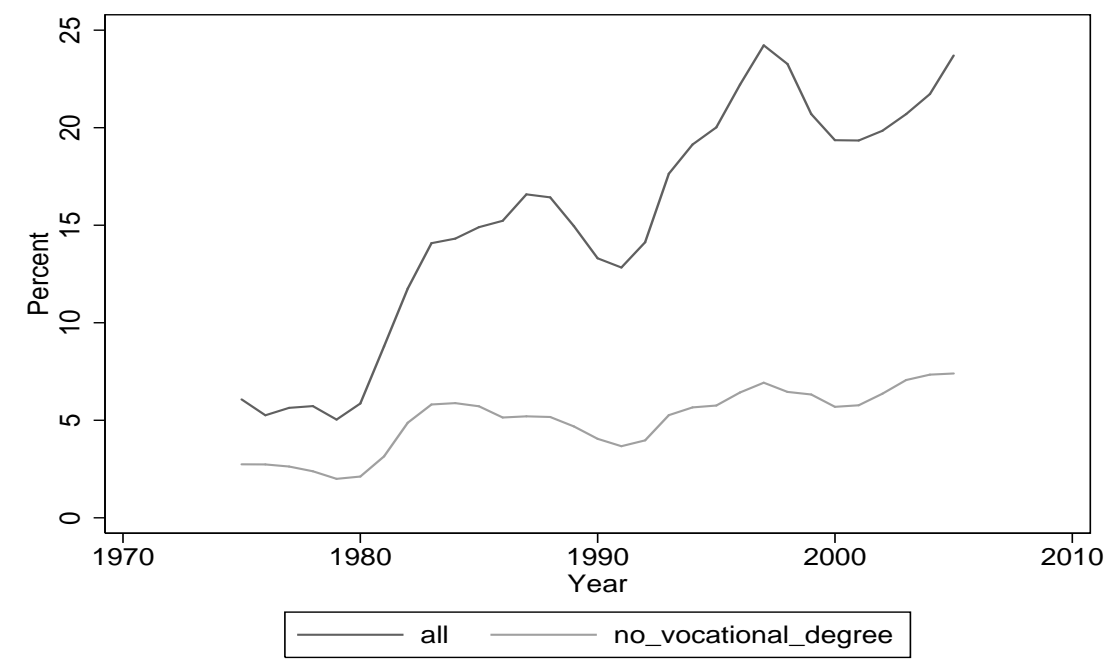

Data Source: Statistisches Bundesamt 2005.

as factors relevant in preparing for and being successful in a labor market with a high demand for workers performing complex tasks. There are three stages at which young people can drop out of the German system of education for low- and mediumskilled workers: first, if they leave school without any degree, second, if they fail to enter an apprenticeship or a professional school after completing lower secondary education, and third, if they drop out of an apprenticeship or professional school without any degree. Someone who obtains a high school degree (Abitur) will by definition not be considered as an educational dropout irrespective of whether he or she completes professional training afterwards. Using data from the German SocioEconomic Panel, we first analyze the determinants of educational dropout during the years directly after leaving school. In the second part we study the effect of educational dropout on the risk of unemployment for persons between the age of 18 and 50 and wages of workers between the age of 25 and 50 .

Our results show that noncognitive skills have a significant impact on educational success, on the employment probability and on wages after controlling for family background in the youth sample and after controlling for formal qualification in the labor market sample. In the youth sample significant effects are found for a psychological measure of noncognitive skills as well as for extracurricular activities that can be seen as a proxy for them. Internet availability at home also significantly reduces the dropout probability while we do not find any significant effect of playing computer games. Unemployment is shown to depend on noncognitive skills in addi- 
tion to education. Considering wages we show that the wage gap between dropouts and the next higher qualification level considerably decreases when controlling for occupations, noncognitive skills and professional Internet use. For men the wage gap vanishes once we control for these variables, for women it still amounts to $4 \%$. The paper is organized as follows: Section 2 reviews selected previous literature, section 3 describes the data set and definitions used. Section 4 analyzes the determinants of educational dropout using probit estimation. Section 5 takes a look on unemployment and Section 6 studies the wage effect of educational dropout. Section 7 concludes.

\section{Previous Literature}

Our paper is related to the literature on labor market integration of low-skilled workers on the one hand and to literatures on the specific role of ICT use and of noncognitive skills on the other hand. A number of papers study the determinants of school career and transition to apprenticeship in the German system. Dustmann (2004) analyzes the link between own and parental education and wages over six decades. He finds that parental background translates, through an association with early ability tracking in the German school system, into sizeable wage differences. Franz et al. (2000) look specifically at the school-to-work transition in the 1980s and the early 1990s. They highlight three stages of school-to-work transition at which failure can occur: (1) the transition from school to vocational training, (2) the completion of vocational training, (3) the transition into employment after training. Our analysis focuses on the first two stages and our definition of educational dropout will encompass all persons that experience failure at one of these stages. Failure at the first stage can result from leaving school without a degree or from not finding an apprenticeship. It is also the stage at which most failures occur, the success rates of graduating from apprenticeship lying well above 90 percent. We contribute to this literature by extending the analysis to noncognitive skills and computer use. Detailed skill data are only available since 2000. Therefore we focus on the completion of education and not on the integration of young people into the labor market.

A growing literature is devoted to the economic role of noncognitive skills (see for example Heckman et al. 2006). Some recent studies include measures of cognitive 
and noncognitive skills and generally find significant effects of both kinds of measures (Rauber (2007), Carneiro et al. (2007)). We use a Rotter index as measure of noncognitive skills. While the concept has long been prevalent in the psychological literature, it has only recently been used in economics. Two previous economic papers constructed a Rotter index from the SOEP data. Flossmann et al. (2007) analyze the effect of noncognitive skills on wages focusing on methodological issues. Uhlendorff (2004) introduces a Rotter index into an analysis of unemployment duration. Both papers find a significant effect of the skill measure on labor market success. In addition to psychological measures, information on extracurricular activities may be a proxy for noncognitive skills, at least insofar the analysis is able to control for factors that determine selection into these activities. Using data from the SOEP, Cornelißen and Pfeifer (2007) analyze the consequences on engaging in sports during childhood and youth on educational outcomes finding a positive effect. While public policy shows a great interest in computers as an educational device and in computer skills, there is little evidence that educational programmes fostering computer use have a positive effect on educational outcomes. Measuring this effect proves, however, quite difficult, because of the heterogeneity of ICT uses and educational settings. The results on private computer use are so far inconclusive. Based on the PISA data including controls for family background and school characteristics, Fuchs and Woessmann (2004) find that the effect of computers at school on student achievement is insignificant while the effect of computers at home is even negative. A contrary result is found by Beltran et al. (2006). Using several empirical strategies that aim at controlling for typically unobserved effects, they find a positive relation between home computer use and high school graduation.

The effect of computer use on wages is more extensively documented. A benchmark value for the average effect of computer use lies somewhat above $5 \%$. Cross section studies without extensive additional controls find higher results. Panel analysis finds lower and in some cases insignificant results. But the results obtained by both methods overlap. Therefore the wage effect of computer use seems to reflect both unobserved heterogeneity and productivity gains (Dolton and Makepiece, 2004). Borghans and ter Weel (2005) look specifically at the wage effect for low-skilled workers, using U.S. data on computer adoption and state differences in minimum wages. They argue that computer adoption is not related to skills but driven by 
differences in wages that do not depend on skills.

This paper goes beyond previous research in studying noncognitive skills and Internet use jointly and focusing on the group of educational dropouts. Moreover, it includes a particular rich set of variables reflecting noncognitive skills using psychological measures as well as information on extracurricular activities.

\section{Data Source and Definitions}

\subsection{The German Socio-Economic Panel}

The German Socio-Economic Panel (SOEP) is a representative national longitudinal data set which surveys households and individuals (Haisken-DeNew and Frick, 2005). In 2006, there were about 12,000 households and more than 21,000 persons sampled in the SOEP. For the empirical investigation we use three sub-samples of the SOEP drawn from seven waves of the years 2000 to 2006.

To study the determinants of educational dropout we use information from the youth questionnaire filled in by 16- and 17-year-olds from the year 2000 on. It provides information on family background like parental education and occupation when the respondents were 15 years old as well as on school activities and achievements, leisure activities and noncognitive skills. The sample also includes information on these individuals from subsequent waves up to 2005. It contains 3,746 observations on individuals in the age between 16 and $22 .{ }^{1}$ We will use the information on 16and 17-year-old individuals as explanatory variables and consider the educational outcome in all available periods as dependent variable.

Additionally, the SOEP provides an informative data base for analyzing labor market outcomes like individuals' occupational status or wages. Because of the still existing structural difference between labor markets in East and West Germany, we limit this analysis to persons living in West Germany. We use all available data for persons on the labor market aged between 18 and 50 to study unemployment. This pooled sample contains 22,587 observations for men and 25,011 for women. Looking subsequently at wages we reduce the sample to those aged between 25 and 50 working at least ten hours a week, obtaining 12,808 observations for men and 10,343 for

\footnotetext{
${ }^{1}$ Because of changes in the questionnaire we do not include the most recent wave from 2006.
} 
women. We exclude observations for younger workers because they contain wages of those in vocational training or working part-time while studying.

The SOEP contains rich information about PC use, but not in an entirely consistent way over years. In the youth questionnaire, information about playing computer games as a leisure activity is collected every year. Different variables of private Internet use also allow to construct a common measure of this variable for all waves of 2000-2005..$^{2}$ Information about professional computer and Internet use is, however, not available beyond 2001. Therefore, when introducing an Internet dummy into the wage regression, we only consider individuals who responded in 2000 or 2001 and measure whether they have adopted Internet use at the workplace by that time.

\subsection{Definition of Educational Dropout}

We define educational dropout with respect to the stages at which young people without advanced general education can fail to integrate into the labor market via the German system of general and vocational education. German children start school at the age of six and normally complete four years of primary school and five to six years of lower-level secondary school. Those who want to earn a degree giving access to higher education complete three more years of upper-level secondary education. The overwhelming majority of schools are public state schools. The secondary schools are traditionally differentiated into three levels, general school (Hauptschule), intermediate school (Realschule) and high school (Gymnasium). The general and the intermediate schools cover only the lower level of secondary schooling. They are conceived to provide general education as a basis for apprenticeship training or professional schools without university status. The majority of vocational training is provided within the dual system where apprentices work in a firm and go to vocational school part-time for two to three years. For some professions only full-time schooling is provided. Secondary school attendance is compulsory for nine to ten years, depending on the regions (Länder). In most regions three years

\footnotetext{
${ }^{2}$ The question is directly asked in the years 2002, 2004, 2005. In 2002 and 2004 information is available on whether Internet access was obtained during the last 12 months. If not, we assume that those who have Internet access already had it the year before. For the year 2000 the variable has to be constructed making additional assumptions and using information on Internet access in 1998 and 2001 and private Internet use (which may differ from access at home) in 2000.
} 
of part-time schooling in the dual system, or, alternatively three years of full-time general or vocational education are compulsory afterwards at least until the age of 18. While some regions and some school types aim at avoiding early ability tracking, most children enter a specific track of secondary school at the age of 10. Primary school teachers recommend a school type for the child, but these recommendations are not binding everywhere.

Nowadays a number of students complete high school before entering an apprenticeship and many graduates of the general and even of the intermediate school encounter problems in entering apprenticeship at all. Special educational measures are targeted at improving these students' preparation for vocational education: the preparation year for vocational training (Berufsvorbereitungsjahr) and the elementary vocational year (Berufsgrundbildungsjahr). The preparation year for vocational training allows students who have left school without any degree to obtain the equivalent of a general school degree and to prepare for transition into the dual system. The elementary vocational year generally requires a school degree and is offered mainly to students who were unable to enter into the dual system. If the student continues education in the dual system afterwards, the elementary vocational year counts towards the fulfillment of the degree requirements of vocational school. In our analysis, a person is considered as an educational dropout if he or she:

- left school without any degree, irrespective of subsequent vocational training

- left school with one of the two lowest school degrees (Hauptschulabschluss or Realschulabschluss) and is neither enrolled in vocational education nor holds a vocational degree

- is enrolled in a preparation year for vocational training (Berufsvorbereitungsjahr) or an elementary vocational year (Berufsgrundbildungsjahr)

- is pursuing a Hauptschulabschluss or a Realschulabschluss and is more than two years behind the regular age for obtaining it.

The definition implies that those in education are generally not considered as dropouts, a status that may change if they leave school or the vocational training system without a degree. In order to account for the fact that some situations of school enrolment are already consequences of a failure of regular integration into 
the vocational training system, we also count as dropouts those who are more than two years behind the age for obtaining a lower-level school degree and still in school as well as those in special measures preparing for vocational training.

\subsection{Rotter's Locus of Control}

While the economic literature traditionally recognizes the importance of cognitive skills for school and labor market success, the link between noncognitive skills and human capital accumulation has been studied only in recent years (Borghans et al., 2008). Noncognitive skills can affect schooling and labor market success through a direct channel. Individuals who have highly pronounced noncognitive skills are more likely to be motivated in doing homework and less likely to skip school. In the labor market, noncognitive skills influence the willingness to work hard, being on time and being trusted (Heckman and Rubinstein, 2001).

In our analysis we use Rotter's Locus of Control (Rotter index) as measure for noncognitive skills that are effective in school and the labor market (Rotter, 1966). This concept, typically used in psychology, is employed to distinguish between two types of personality. Respondents are confronted with two sorts of statements that express judgements about the personal situation or life in general in opposite ways. One category of statements sees luck as the determining force of success and failure. The other category sees individual skills and actions as the determining force. According to their degree of agreement with the statements, individuals can be divided into two types, the externaliser and the internaliser. Externalisers attribute outcomes to external circumstances, while internalisers attribute outcomes to their own control. Internalisers are considered to have stronger noncognitive skills such as motivation, interest and self-esteem.

In order to construct a Rotter index we use 10 items from the youth and the personality questionnaires. The items are ranked on a four-point scale in the youth questionnaire and on a seven-point scale for workers (see Table 1, all Tables are in Appendix). In the youth questionnaire the items are included every year. For workers, the Rotter index is only available for the year 2005. It is assumed that the skills derived from this index are stable over time, at least for persons older than 25. We sum up all items to obtain a unidimensional scale (see Table 1). The scale ranges between 10 to 40 in the youth sample and between 10 to 70 in the sample 
Figure 2: Locus of Control for 17-year-olds

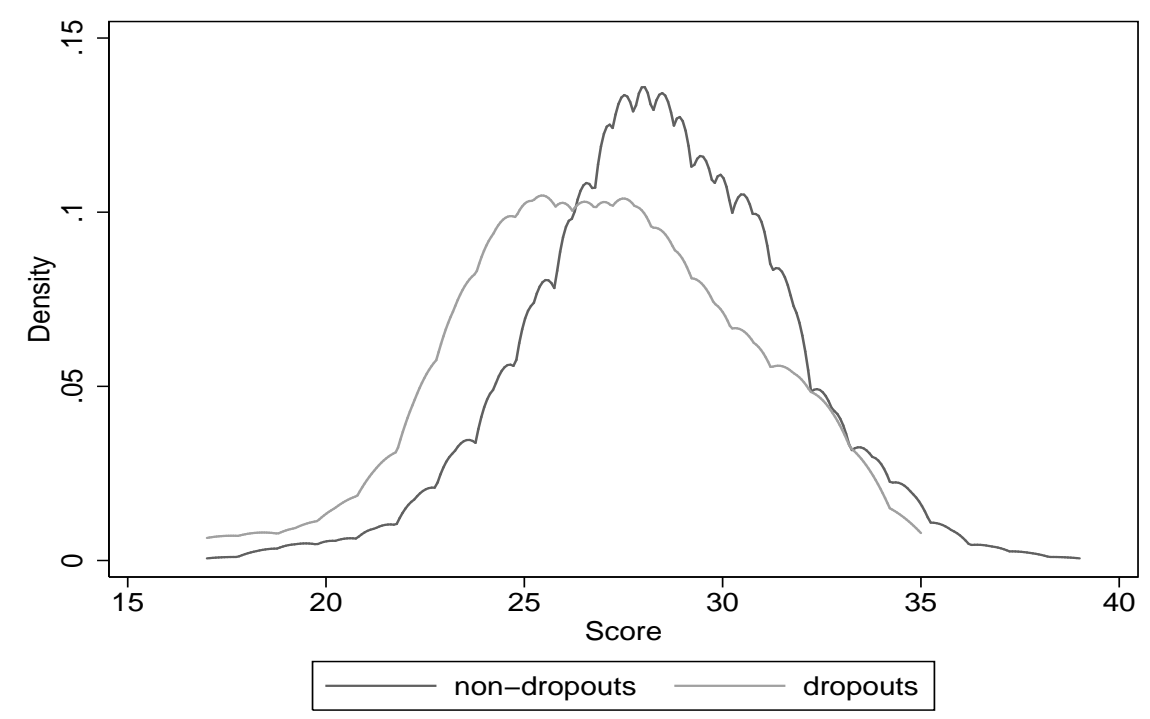

Data Source: Sample drawn from the SOEP 2000-2005. Own calculation.

of the working population (Rotter, 1966). High levels indicate strong noncognitive skills (internalisers), low levels indicate weak noncognitive skills (externalisers).

Table 1 presents the means for all items and the overall noncognitive skill indicator (Rotter index), separately for educational dropouts and other individuals. Additionally, we compute t-tests to examine whether these groups differ significantly with respect to noncognitive skills. The results indicate that educational dropouts have significantly lower noncognitive skills than better educated individuals (see also Figure 2). For some items significant differences also exist for men and women, but not always in the same direction. ${ }^{3}$ Differences between women and men in terms of the overall noncognitive skill indicator (Rotter's Locus of Control) are not significant.

\footnotetext{
${ }^{3}$ Unreported results.
} 


\section{Determinants of Educational Dropout}

\subsection{Descriptive Statistics}

Table 2 reports descriptive statistics for the whole youth sample and by dropout status. It contains sample means and standard deviations of all variables used in the estimation. Table 3 displays selected variables by gender. The share of dropouts is $8.8 \%$. We consider that school recommendations partly reflect cognitive skills. On average, $13 \%$ of all individuals in the youth sample had a general school (Hauptschule) recommendation. Among dropouts the share is $28 \%$ and among young men $17 \%$. We use the recommendation instead of the type of school attended because the attendance of a particular type of school is already part of our definition of potential dropouts.

Besides cognitive skills noncognitive skills play an important role in determining educational success. In addition to the Rotter index (see discussion above) the variables "class representative", "music", "sports" and "playing computer games" are measures which might reflect parts of individual noncognitive skills. They can be used as proxy variables for unobserved motivation, self-discipline, time-preference, authority and self-control. Two thirds of all individuals regularly engage in sports, $21 \%$ in music and $51 \%$ in playing computer games. About one third of all respondents have been a class representative at some time in their school career. Engagement in sports and music and as a class representative is more prevalent among non-dropouts while there is no difference in the share of those regularly playing computer games. Meanwhile the gender difference is strong with $71 \%$ of young men playing computer games and $31 \%$ of young women. Men are also somewhat more likely to engage in sports while women are more likely to engage in music.

While regular playing of computer games is expected to reflect the aspects of computer use that might be detrimental to educational outcomes, Internet access at home may have both positive and negative effects. Positive effects come from the use of Internet as an educational technology for looking up information, doing homework or communicating with teachers and other students. When looking at the lower tail of the educational distribution one also has to take into account that Internet as an interactive technology encourages the practice of reading and writing. Internet access at home is available to $56 \%$ of the non-dropout compared to $30 \%$ of dropouts. 
In the lower part of Table 2 we look at descriptive statistics for the family background. All information on the parents refers to characteristics when individuals were 15 years old. The overall pattern is that on average parental educational attainment is lower than the attainment of the offspring. ${ }^{4}$ With regard to schooling, there are no large differences between mothers and fathers. In contrast, differences between females and males regarding occupational degrees are pronounced in the parents' generation. The share of individuals who grew up with both parents until the age of 15 is about $80 \%$. Finally, the share of individuals with migration background is about $20 \% .^{5}$

\subsection{Regression Analysis}

Table 4 presents the regression results for the first part of our analysis that considers determinants of educational dropout. Results, based on probit regressions, are reported for the entire sample for 2000 to 2005 and separately for young men and women. First, we investigate the influence of skill measures and computer use on educational success, excluding family characteristics from regression. Then, we include a variety of family background information to analyse changes in the impact of skills and computer use on the probability to drop out. Explanatory variables are obtained from the year in which respondents filled in the youth questionnaire for 16- and 17-year-olds. The dependent variable is based on information from all periods. To take into account the fact that the probability to be a dropout in one educational stage influences the probability to be a dropout in subsequent stages, we cluster the standard errors in our pooled sample at the individual level. Through this clustering we allow for serial correlation within a cluster but we do not allow for serial correlation between clusters. ${ }^{6}$

Explanations of differences between low- and high-educated individuals are often based on the family background and sometimes on cognitive skills. Our interest lies in the additional effect of noncognitive skills and Internet use once these effects

\footnotetext{
${ }^{4}$ The category "Hauptschule" for the parents also includes those without any school degree.

${ }^{5}$ The dummy for immigration takes the value one if the individual belongs to the first or second generation of immigrants and zero otherwise.

${ }^{6}$ The cluster size varies between one and six observations.
} 
are controlled for. The interpretation of these findings requires caution: In our probit estimation it is evident that unobserved third factors, for instance unobserved abilities, affect both observed skills and educational outcomes. Unfortunately, the data contain no identifying information to disentangle the effect of cognitive and noncognitive skills on educational attainment. However, the fact that the association between skills and educational attainment is robust to the addition of controls for a rich set of family background variables strengthens the credibility of a causal interpretation. $^{7}$ In a similar vein, it can be objected that Internet availability at home is endogenous. Controlling for parental education, income and occupational status should at least eliminate the most obvious sources of endogeneity.

In the joint regression for females and males, the Rotter index for noncognitive skills, regular engagement in music and sports and being a class representative all have a negative effect on educational dropout that remains significant after controlling for personal and family characteristics. Thus noncognitive skills clearly reduce the probability to become an educational dropout.

In separate regressions for females and males, the effect of sports remains significant for both. It reduces male dropout probability by $3.4 \%$ and female dropout probability by $6.1 \%$. The robust effect of sports supports earlier findings by Cornelißen and Pfeifer (2007). The Rotter index and being a class representative have a significant effect only for men, while engaging in music has a significant effect only for women. The fact that the Rotter index and several extracurricular activities are significant in the same regression underlines the multidimensionality of noncognitive skills and points to different channels through which young people develop skills important for educational success.

It is often argued that early tracking increases inequality later on. Our results confirm previous results that young adults who obtained a recommendation for the Hauptschule (lowest secondary school track) after primary school are more likely to be educational dropouts. In separate regressions, the result is only significant for males, who also have a higher share of recommendations for the Hauptschule. The availability of Internet at home has a five percent raw effect on dropout prob-

\footnotetext{
${ }^{7}$ Estimating fixed effect models is not possible, since information on skills is only observable at the age of 17 .
} 
ability and the effect still amounts to three percent after controlling for personal and family characteristics, which include in particular the household's net income. This result is in line with Beltran et al. (2006) who find robust positive effects of computers in the household on educational outcomes and contrasts with Fuchs and Woessmann (2004) who find negative effects of computers (using, however, not the same definition of educational outcome). So we find evidence that the benefits of Internet access seem to outweigh the harmful effects on educational outcomes from Internet as a means of entertainment and distraction. Besides direct effects of Internet use, the result may reflect skills and attitudes present in families that have Internet access, such as openness to new technologies and a positive attitude towards learning. Regular playing of computer games does not have a significant effect in any specification. This is in line with the descriptive statistics that show that while being more prevalent among young men than among young women, regular playing of computer games is as prevalent among dropouts as among non-dropouts. ${ }^{8}$ It is possible that negative effects of computer playing would only show up if a person is known to play several hours a day. This information is not present in the data. In addition, all models contain measures for the parental background such as parents' school education, parents' vocational training and parents' occupation. We also include family composition and find that growing up with both parents until the age of 15 significantly reduces the probability of being an educational dropout for young men.

\section{Unemployment Effects of Educational Dropout}

We analyze the determinants of unemployment for a subsample of persons on the labor market aged between 18 and 50 living in West Germany. We do not include older workers in order to exclude effects of early retirement and too heterogenous cohorts. In our sample the unemployment rate is $4.1 \%$ for non-dropouts and $12.2 \%$ for dropouts. Tables 6 and 7 show marginal effects on the probability to be unemployed. From specification 1 to 4 we stepwise add more explaining variables. In specification

\footnotetext{
${ }^{8}$ Internet availability and regular playing of computer games are only weakly correlated with a coefficient of correlation of 0.13 . One reason is that PC ownership is not necessary for playing computer games as those may also be played on play stations.
} 
(1) we only control for age and birth cohort. Male dropouts have a $11.1 \%$ higher risk of unemployment, female dropouts have a higher risk of $5.3 \%$. Independently of the dropout status the unemployment risk decreases with age. Adding more control variables the direct effect of the dropout status on being unemployed reduces to $5.2 \%$ for male dropouts and $1.8 \%$ for female dropouts in specification (3). Persons with migration background have a significantly higher risk of unemployment. Higher noncognitive skills, measured by the Rotter index, reduce the risk of unemployment. For males and females a ten point higher Rotter index reduces the risk of unemployment by $3 \%$. Introducing additionally interaction terms between dropout status and migration background as well as dropout status and the Rotter index renders the main effect of the dropout status insignificant. This may to some extent be due to multicollinearity. Meanwhile the interaction term between dropout status and the Rotter index is significantly negative for women.

\section{$6 \quad$ Wage Effects of Educational Dropout}

\subsection{Descriptive Statistics}

According to the descriptive statistics of Table 5, educational dropouts experience lower hourly wages than non-dropouts. But at the beginning of working life they earn higher wages (see Figure 3). This could be the case because they are participating already in the labor market while other persons are still in education. Looking at the lifetime wage profiles, we observe a relatively flat wage profile for dropouts while wages of non-dropouts increase faster and later in life significantly exceed wages of dropouts.

To handle these different effects of the dropout status on wages, we restrict our sample to persons aged between 25 and 50 years and to employed persons living in West Germany who work more than ten hours a week. Also, to reduce the risk of measurement error from extreme wage values, we trim the highest one percent and the lowest one percent of observations on hourly wages. The outcome variable (real gross hourly wage) is obtained for all workers including the self-employed by dividing the gross earnings per month prior to the interview (not adjusted for end-of-year bonuses) by the reported working hours of the last week (multiplied by 4.45). Wages are deflated using the consumption price index based on the year 2000 to obtain real 
Figure 3: Wage Development

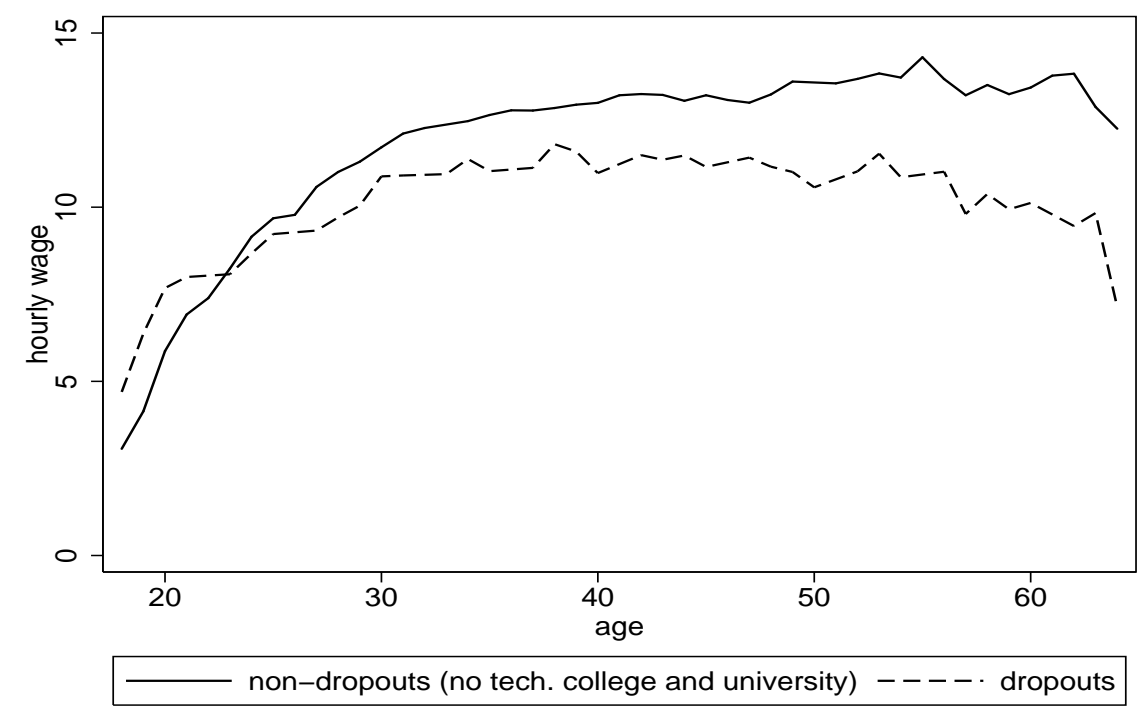

Data Source: Sample drawn from the SOEP 2000-2006. 31625 observations for dropouts, 6076 for non-dropouts. Own calculation. Here, the category 'non-dropouts' contains workers with completed vocational training and excludes those with a degree from a technical college or university.

consumption wages of comparable purchasing power.

In addition to average wages, Table 5 shows descriptive statistics for selected explanatory variables separately for males and females as well as for dropouts and non-dropouts. Male dropouts in the sample are on average younger than female dropouts. The share of persons with migration background is more than twice as high among dropouts as among non-dropouts. By contrast, the share of persons using the Internet at their workplace is more than twice as high for non-dropouts as for dropouts. Also the Rotter index which potentially varies between 10 (total externaliser) and 70 (total internaliser) is higher for non-dropouts.

For the specification of the occupational categories we use the International Standard Classification of Occupations (ISCO 88). The distribution across occupational categories is reported in Table (5) at the one-digit level. Nearly three quarters of male dropouts work as craft workers, plant and machine operators and in related occupations, or in elementary occupations. Among craft workers, which mainly include workers in extraction, construction and in metal and machinery related trades, the proportion of dropouts is roughly equal to the proportion of non-dropouts. Meanwhile, dropouts are strongly over-represented among plant and machine operators and assemblers (which include drivers) and in elementary occupations. A main category of elementary occupations are laborers in mining, construction, manufacturing 
and transport.

Nearly half of the female dropouts work as service and sales workers, which include in particular restaurant personnel, and in elementary occupations, most women there working as cleaners. In both categories, dropouts are over-represented compared to other occupations. Among clerks, which represent $17 \%$ of the female dropouts, the proportion of non-dropouts is nearly equal. In the category technicians and associate professionals female dropouts are under-represented with a share of $18 \%$ compared to a share of $33 \%$ of more educated female workers. Main occupations in this category are administrative occupations such as bookkeepers or government employees as well as social workers.

While only a minor share of all workers works as managers or professionals, it is noticeable that the share of dropouts who are managers is relatively high with $5 \%$. These include mainly owners or managers of hotels, restaurants and wholesale or retail firms.

\subsection{Regression Analysis}

Table 8 and Table 9 show the wage regressions based on the sample described in Section 6.1. Results are reported separately for males and for females. As dependent variable we use log hourly wages and add progressively more control variables to analyze the development of the effect of being a dropout. We control for six educational levels, the lowest being the dropout status. Because of data restrictions, we cannot instrument educational levels but introduce them directly into the wage regression. As education is partly endogenous, the corresponding coefficients should be interpreted as correlations, not in a strictly causal way. As in the probit estimation, unobserved abilities affect observed skills and outcomes.

In the parsimonious estimation where we only control for age and four birth cohort dummies (born 1960 or earlier, born between 1961 and 1967, born between 1968 and 1974, born 1975 or later) the fact of being a dropout by our definition reduces the hourly wage by about 15 percent for males and even 22 percent for females. In a second step, we also control for year effects and higher educational degrees. We include dummies for the following categories: high school degree only, high school degree and vocational training, degree from a technical college, degree from a university. The reference category is completed lower secondary education and 
vocational training. Year effects turn out to be rather small. In general higher education levels lead to higher wages. By our definition, dropouts do not achieve any of these higher degrees. Apparently, the negative influence of being a dropout decreases if we control for more individual characteristics. This trend is continuous over all specifications.

In specification (3), we add controls for firm size (less than 20 employees, 20 to 199 employees, 200 to 1,999 employees, more than 2,000 employees), industries and occupations. ${ }^{9}$ As shown in the descriptive statistics, there is a strong occupational segregation between women and men, and, to a lesser extent, between dropouts and non-dropouts. In the regression, the category of clerks, with a roughly equal representation of dropouts and non-dropouts, was chosen as a reference category. For all occupational categories with a high proportion of dropouts compared to nondropouts (plant and machine operators, elementary occupations and female service, shop and sales workers), there is a pronounced negative wage effect. Meanwhile male craft workers, which include similar high shares of dropouts and non-dropouts, experience only a weak negative wage effect compared to office clerks. Female associate professionals, which include a large number of dropouts but a relatively low share, earn on average higher wages than office clerks. Thus a part of the effect of educational dropout on wages becomes manifest in occupational segregation. ${ }^{10}$

In specification (4) we additionally include the Rotter index and in specification (5), Internet use at the workplace is added. Both variables have coefficients with the expected sign and are significant. Higher noncognitive skills are associated with higher wages and the same is true if the worker has started using Internet at the workplace by 2001. Using the Internet is related with a wage premium of 9 percent for males and of 6 percent for females. From specification (3) on, which adds occupational groups, the fact of being a dropout has no separate explanatory power anymore for males. Meanwhile being a dropout has still a significant negative influence for females in specification (5), where it amounts to $4.1 \%$.

In a further extension, we add interaction terms between being a dropout and the

\footnotetext{
${ }^{9}$ Reference categories are the smallest firm size, the agricultural sector, and clerks.

${ }^{10}$ In an unreported regression we have examined whether the effect of occupationa differ between dropouts and non-dropouts. The results are not significant.
} 
migration background, the Rotter index and Internet use (see specification (6)). Interestingly, dropouts with a migration background seem to earn higher wages than other dropouts. With regard to Internet use and noncognitive skills, we note that these variables do not display any additional effect for educational dropouts if interacted with the dropout dummy. Moreover, the inclusion of interaction terms renders the effect of being a dropout in the reference category insignificant for both males and females. A reason for this may be the high collinearity among the interaction terms and between the interaction terms and the main effect of being a dropout.

\section{Conclusion}

In this study, we investigate the determinants of educational dropout in Germany and its effect on employment and wages, paying particular attention to factors that are important in an increasingly complex work environment. More specifically, we focus on noncognitive skills and Internet use which potentially play a role both in completing education and in being successful on the labor market. While psychologists have for a long time focused on noncognitive skills as an important determinant of individual success, economists have only recently begun to analyze the importance of these skills. We use the Rotter index as a measure of noncognitive skills. It reflects personality traits such as motivation, interest and self-regulation. In studying the determinants of educational dropout, we further consider extracurricular activities as proxies for noncognitive skills. Moreover, variables of Internet availability at home and at work are included.

Based on individual data from the SOEP, we have found the following main results: Higher noncognitive skills have positive effects on school attainment as well as on individuals' employment probability and earnings. In the youth sample, an increase in the Rotter index on a scale from 10 to 40 by 5 points reduces the dropout probability by $4 \%$. Engaging in sports and having been a class representative decreases the dropout probability by $3.4 \%$ and $4.4 \%$ respectively. For women, the Rotter index does not remain significant after controlling for family background, but engaging in music and sports reduces the dropout probability by $4.7 \%$ and $6.1 \%$ respectively. The fact that several proxies for noncognitive skills are significant points to their multidimensionality.

Looking at labor market outcomes, a 10 point increase in the Rotter index on a scale 
from 10 to 70 reduces unemployment probability by $3 \%$ and raises wages by $4 \%$. It is noticeable that separate regressions for men and women obtain the same magnitude for these effects. Meanwhile the direct effect of being a dropout appears to be higher for men when looking at the unemployment probability and higher for women when looking at wages. Controlling for additional characteristics such as occupations, Internet use and noncognitive skills, the wage gap between dropouts and those with completed lower secondary school and professional education vanishes for men. For females the wage gap is reduced to four percent.

The expected positive association between computer use and wages is found in the wage regressions, which introduce Internet use at work, with no difference between dropouts and non-dropouts. Examining the more contested effect of computer use on educational success we find an insignificant effect of regular computer playing and a positive effect of Internet availability at home. The latter remains significant after controlling for parental education and income.In order to better understand the overall effect of the increasing availability of ICT on educational outcomes, future research should aim at using data that detail different ICT uses and the duration of use per week.

With more waves of the SOEP becoming available, the cohorts for which information from the youth questionnaire is present can be observed over a longer time horizon. Using these data, it will be possible to study the effect of multidimensional noncognitive skills developed in youth on the long-term labor market success. 


\section{References}

Autor, D. H., Levy, F. and Murnane, R. J. (2003). The Skill Content of Recent Technological Change: An Empirical Exploration, Quarterly Journal of Economics 118(4): 1279-1333.

Beltran, D. O., Das, K. K. and Fairlie, R. W. (2006). Do Home Computers Improve Educational Outcomes? Evidence from Matched Current Population Surveys and the National Longitudinal Survey of Youth 1997, IZA Discussion Paper No. 1921 .

Borghans, L., Duckworth, A. L., Heckman, J. and ter Weel, B. (2008). The Economics and Psychology of Personality, forthcoming in Journal of Human Resources $43(4)$.

Borghans, L. and ter Weel, B. (2005). Computer Adoption and Diffusion at the Bottom of the U.S. Labor Market: Disentangling the Effects of Skills and Wages on Computer Use, Working paper, Maastricht University .

Carneiro, P., Crawford, C. and Goodman, A. (2007). The Impact of Early Cognitive and Non-Cognitive Skills on Later Outcomes, Working paper, Centre for Economics of Education.

Cornelißen, T. and Pfeifer, C. (2007). The Impact of Participation in Sports on Educational Attaiment: New Evidence From Germany, IZA Discussion Paper No. 3160 .

Dolton, P. and Makepiece, G. (2004). Computer use and earnings in Britain, Economic Journal 114: C114-C129.

Dustmann, C. (2004). Parental background, secondary school track choice, and wages, Oxford Economic Papers 56: 209-230.

Flossmann, A. L., Piatek, R. and Wichert, L. (2007). Going Beyond Returns to Education: The Role of Noncognitive Skills on Wages in Germany, University of Konstanz, Unpublished Paper .

Franz, W., Inkmann, J., Pohlmeier, W. and Zimmermann, V. (2000). Young and Out in Germany. On Youths' Chances of Labor Market Entrance in Germany., in 
D. Blanchflower and R. B. Freeman, eds., Youth Unemployment and Joblessness in Advanced Countries, Chicago Press.

Fuchs, T. and Woessmann, L. (2004). Computers and Student Learning: Bivariate and Multivariate Evidence on the Availability and Use of Computers at Home and at School, Brussels Economic Review 47: 359-385.

Haisken-DeNew, J. and Frick, J. R. (2005). DTC Desktop Companion to the German Socio-Economic Panel (SOEP), DIW Berlin .

Heckman, J. J. and Rubinstein, Y. (2001). The Importance of Noncognitive Skills: Lessons from the GED Testing Program, American Economic Review 91: 145149.

Martin, J. P., Martin, S. and Quintini, G. (2007). The Changing Nature of the School-to-Work Transistion Process in OECD Countries, IZA Discussion Paper No. 2582 .

Rauber, M. (2007). Noncognitive Skills and Success in Life: The Importance of Motivation and Self-Regulation, Working paper, University of Kostanz .

Rotter, J. (1966). Generalized Expectancies for Internal versus External Control of Reinforcement, Psychological Monographs, 80 .

Spitz-Oener, A. (2006). Technical Change, Job Tasks and Rising Educational Demands: Looking outside the Wage Structure, Journal of Labor Economics 24(2): $235-270$.

Uhlendorff, A. (2004). The influence of personality characteristics and social resources on unemployment duration, Kölner Zeitschrift für Soziologie und Sozialpsychologie 56(2): 279-303. 


\section{A Appendix}

Table 1: Rotter's Locus of Control

\begin{tabular}{|c|c|c|c|c|c|c|}
\hline \multirow[b]{2}{*}{ Statement } & \multicolumn{2}{|c|}{ Youth mean } & \multirow[b]{2}{*}{ t-value } & \multicolumn{2}{|c|}{ Worker mean } & \multirow[b]{2}{*}{ t-value } \\
\hline & Dropout & $\begin{array}{l}\text { Non- } \\
\text { dropout }\end{array}$ & & Dropout & $\begin{array}{l}\text { Non- } \\
\text { dropout }\end{array}$ & \\
\hline I decide the way my life is run & 3.47 & 3.50 & 0.88 & 5.53 & 5.55 & 0.29 \\
\hline $\begin{array}{l}\text { Compared to others, I haven't } \\
\text { attained what I deserve }\end{array}$ & 2.81 & 3.11 & 6.96 & 4.31 & 4.99 & 8.53 \\
\hline $\begin{array}{l}\text { What you achieve in life is } \\
\text { mainly a matter of fate or luck }\end{array}$ & 2.56 & 2.80 & 5.27 & 3.95 & 4.61 & 8.83 \\
\hline $\begin{array}{l}\text { Experience that others deter- } \\
\text { mine my life }\end{array}$ & 2.26 & 2.42 & 3.66 & 4.89 & 4.92 & 0.43 \\
\hline $\begin{array}{l}\text { In case of difficulties doubts } \\
\text { about own abilities }\end{array}$ & 2.75 & 2.94 & 5.50 & 4.61 & 4.77 & 2.06 \\
\hline Little control over life & 3.47 & 3.42 & -1.66 & 5.28 & 5.52 & 3.64 \\
\hline $\begin{array}{l}\text { One has to work hard to } \\
\text { achieve success }\end{array}$ & 2.55 & 2.75 & 4.48 & 6.16 & 5.94 & -4.46 \\
\hline $\begin{array}{l}\text { Possibilities limited by social } \\
\text { conditions }\end{array}$ & 2.14 & 2.33 & 4.82 & 3.42 & 3.68 & 3.85 \\
\hline $\begin{array}{l}\text { Abilities are more important } \\
\text { than effort }\end{array}$ & 1.93 & 2.01 & 2.13 & 2.97 & 3.19 & 3.63 \\
\hline $\begin{array}{l}\text { Social and political active in- } \\
\text { fluence social conditions }\end{array}$ & 2.96 & 3.13 & 4.07 & 3.34 & 3.63 & 3.75 \\
\hline $\begin{array}{l}\text { Locus of Control (all state- } \\
\text { ments) }\end{array}$ & 26.89 & 28.42 & 8.33 & 44.47 & 46.79 & 7.37 \\
\hline Observations & 331 & 3,415 & & 517 & 4,207 & \\
\hline
\end{tabular}

Data Source: Sample drawn from the SOEP 2000-2005 for youth and only from the SOEP 2005 for workers living in West Germany and aged between 25 and 50. Own calculation. We adjust the scale of these items in order to provide a uniform scale. For all items it is essential that higher values indicate higher noncognitive skills. 
Table 2: Summary Statistics by Dropout Status

\begin{tabular}{|c|c|c|c|c|c|c|}
\hline & \multicolumn{2}{|c|}{ All } & \multicolumn{2}{|c|}{ Dropouts } & \multicolumn{2}{|c|}{ Non-dropouts } \\
\hline & mean & std.dev. & mean & std.dev. & mean & std.dev. \\
\hline Dropouts & 0.088 & $(0.28)$ & - & - & - & - \\
\hline Rotter index & 28.28 & $(3.22)$ & 26.89 & $(3.56)$ & 28.42 & $(3.15)$ \\
\hline School recommendation & 0.13 & $(0.34)$ & 0.28 & $(0.45)$ & 0.12 & $(0.32)$ \\
\hline Class representative & 0.34 & $(0.47)$ & 0.22 & $(0.41)$ & 0.35 & $(0.48)$ \\
\hline Music & 0.21 & $(0.41)$ & 0.07 & $(0.26)$ & 0.22 & $(0.42)$ \\
\hline Sport & 0.66 & $(0.47)$ & 0.43 & $(0.50)$ & 0.68 & $(0.46)$ \\
\hline Playing computer games & 0.51 & $(0.50)$ & 0.51 & $(0.50)$ & 0.51 & $(0.50)$ \\
\hline Internet at home & 0.54 & $(0.50)$ & 0.30 & $(0.46)$ & 0.56 & $(0.50)$ \\
\hline Grew up with both parents & 0.80 & $(0.40)$ & 0.71 & $(0.46)$ & 0.80 & $(0.40)$ \\
\hline $\begin{array}{l}\text { Father Hauptschule (or no de- } \\
\text { gree) }\end{array}$ & 0.49 & $(0.50)$ & 0.64 & $(0.48)$ & 0.47 & $(0.50)$ \\
\hline Father Realschule & 0.31 & $(0.46)$ & 0.29 & $(0.45)$ & 0.31 & $(0.46)$ \\
\hline Father Gymnasium & 0.20 & $(0.41)$ & 0.07 & $(0.27)$ & 0.22 & $(0.41)$ \\
\hline Father no vocational degree & 0.07 & $(0.25)$ & 0.14 & $(0.34)$ & 0.06 & $(0.24)$ \\
\hline Father low vocational degree & 0.60 & $(0.49)$ & 0.77 & $(0.42)$ & 0.59 & $(0.49)$ \\
\hline Father high vocational degree & 0.10 & $(0.30)$ & 0.04 & $(0.19)$ & 0.10 & $(0.31)$ \\
\hline Father University degree & 0.23 & $(0.43)$ & 0.07 & $(0.25)$ & 0.25 & $(0.43)$ \\
\hline Father Blue collar worker & 0.38 & $(0.48)$ & 0.48 & $(0.50)$ & 0.37 & $(0.48)$ \\
\hline Father White collar worker & 0.31 & $(0.46)$ & 0.19 & $(0.39)$ & 0.32 & $(0.47)$ \\
\hline Father Self-employed & 0.11 & $(0.32)$ & 0.05 & $(0.23)$ & 0.12 & $(0.33)$ \\
\hline Father Civil servant & 0.09 & $(0.29)$ & 0.04 & $(0.19)$ & 0.10 & $(0.30)$ \\
\hline $\begin{array}{l}\text { Mother Hauptschule (or no de- } \\
\text { gree) }\end{array}$ & 0.44 & $(0.50)$ & 0.63 & $(0.48)$ & 0.42 & $(0.49)$ \\
\hline Mother Realschule & 0.41 & $(0.49)$ & 0.31 & $(0.46)$ & 0.42 & $(0.49)$ \\
\hline Mother Gymnasium & 0.15 & $(0.36)$ & 0.06 & $(0.23)$ & 0.14 & $(0.35)$ \\
\hline Mother no vocational degree & 0.15 & $(0.36)$ & 0.21 & $(0.41)$ & 0.14 & $(0.34)$ \\
\hline Mother low vocational degree & 0.62 & $(0.49)$ & 0.70 & $(0.46)$ & 0.61 & $(0.49)$ \\
\hline Mother high vocational degree & 0.05 & $(0.21)$ & 0.01 & $(0.11)$ & 0.05 & $(0.22)$ \\
\hline Mother University degree & 0.18 & $(0.39)$ & 0.08 & $(0.26)$ & 0.23 & $(0.42)$ \\
\hline Mother Blue collar worker & 0.24 & $(0.42)$ & 0.32 & $(0.47)$ & 0.22 & $(0.42)$ \\
\hline Mother White collar worker & 0.40 & $(0.49)$ & 0.25 & $(0.43)$ & 0.41 & $(0.49)$ \\
\hline Mother Self-employed & 0.07 & $(0.25)$ & 0.04 & $(0.20)$ & 0.07 & $(0.26)$ \\
\hline Mother Civil servant & 0.06 & $(0.24)$ & 0.02 & $(0.13)$ & 0.07 & $(0.25)$ \\
\hline Household's (net) income & 2981 & $(1607)$ & 2301 & $(1225)$ & 3047 & $(1509)$ \\
\hline Female & 0.51 & $(0.50)$ & 0.42 & $(0.49)$ & 0.51 & $(0.50)$ \\
\hline Age & 18.45 & $(1.45)$ & 18.89 & $(1.62)$ & 18.41 & $(1.43)$ \\
\hline Migration background & 0.20 & $(0.40)$ & 0.24 & $(0.43)$ & 0.20 & $(0.40)$ \\
\hline West Germany & 0.72 & $(0.45)$ & 0.66 & $(0.47)$ & 0.72 & $(0.44)$ \\
\hline Observations & 3,746 & & 331 & & 3,415 & \\
\hline
\end{tabular}

Data Source: Sample drawn from the SOEP 2000-2005. Own calculation. All variables except Rotter index are dummy variables. 
Table 3: Summary Statistics by Gender

\begin{tabular}{llclc}
\hline \hline & \multicolumn{2}{c}{ Males } & \multicolumn{2}{c}{ Females } \\
& mean & std.dev. & mean & std.dev. \\
\hline Dropouts & 0.10 & $(0.31)$ & 0.07 & $(0.26)$ \\
Rotter index & 28.38 & $(3.27)$ & 28.19 & $(3.16)$ \\
School recommendation & 0.17 & $(0.37)$ & 0.11 & $(0.31)$ \\
Class representative & 0.33 & $(0.47)$ & 0.35 & $(0.48)$ \\
Music & 0.19 & $(0.39)$ & 0.22 & $(0.42)$ \\
Sport & 0.71 & $(0.46)$ & 0.62 & $(0.49)$ \\
Playing computer games & 0.71 & $(0.45)$ & 0.31 & $(0.46)$ \\
Internet at home & 0.56 & $(0.50)$ & 0.52 & $(0.50)$ \\
Age & 18.43 & $(1.45)$ & 18.47 & $(1.45)$ \\
Migration background & 0.20 & $(0.40)$ & 0.21 & $(0.41)$ \\
West Germany & 0.71 & $(0.46)$ & 0.72 & $(0.45)$ \\
\hline Observations & 1,851 & & 1,895 & \\
\hline \hline Data Sour: Sample & & &
\end{tabular}

Data Source: Sample drawn from the SOEP 2000-2005. Own calculation. 
Table 4: Determinants of Dropout

\begin{tabular}{|c|c|c|c|c|c|c|}
\hline \multirow[b]{3}{*}{ Rotter index } & \multicolumn{6}{|c|}{$\begin{array}{l}\text { Dependent variable: probability of being a dropout } \\
\text { Marginal effects based on probit estimations }\end{array}$} \\
\hline & \multicolumn{2}{|c|}{ All } & \multicolumn{2}{|c|}{ Males } & \multicolumn{2}{|c|}{ Females } \\
\hline & $-0.007^{* * *}$ & $-0.005^{* * *}$ & $-0.011^{* * *}$ & $-0.008^{* * *}$ & -0.003 & -0.001 \\
\hline School recommendation & $0.07^{* * *}$ & $0.051^{* * *}$ & $0.08^{* * *}$ & $0.07^{* * *}$ & $0.049 * *$ & 0.036 \\
\hline Class representative & $-0.031^{* * *}$ & $-0.021^{*}$ & $-0.054^{* * *}$ & $-0.044^{* * *}$ & -0.01 & -0.004 \\
\hline Music & $-0.047^{* * *}$ & $-0.034^{* * *}$ & -0.033 & -0.008 & $-0.053^{* * *}$ & $-0.047 * * *$ \\
\hline Sports & $-0.06^{* * *}$ & $-0.048^{* * *}$ & $-0.048^{* * *}$ & $-0.034^{* *}$ & $-0.073^{* * *}$ & $-0.061^{* * *}$ \\
\hline Computer games & 0.019 & 0.01 & 0.013 & 0.018 & -0.001 & -0.002 \\
\hline Internet at home & $-0.05^{* * *}$ & $-0.030^{* * *}$ & $-0.052^{* * *}$ & $-0.028^{*}$ & $-0.052^{* * *}$ & $-0.037^{* * *}$ \\
\hline Female & & $-0.028^{* * *}$ & & & & \\
\hline age & & 0.071 & & 0.04 & & 0.11 \\
\hline age2 & & -0.001 & & -0.0007 & & -0.003 \\
\hline Migration background & & -0.01 & & -0.004 & & -0.024 \\
\hline West Germany & & $-0.029^{*}$ & & $-0.072^{* * *}$ & & 0.03 \\
\hline Grew up with both parents & & $-0.027^{* *}$ & & $-0.037^{*}$ & & -0.004 \\
\hline Father's education & no & yes & no & yes & no & yes \\
\hline Father's vocational training & no & yes & no & yes & no & yes \\
\hline Father's occupation & no & yes & no & yes & no & yes \\
\hline Mother's education & no & yes & no & yes & no & yes \\
\hline Mother's vocational training & no & yes & no & yes & no & yes \\
\hline Mother's occupation & no & yes & no & yes & no & yes \\
\hline Household's (net) income & no & yes & no & yes & no & yes \\
\hline Observations & 3,746 & 3,746 & 1,851 & 1,851 & 1,895 & 1,895 \\
\hline Wald-test & $217.14^{* * *}$ & $146.37^{* * *}$ & $81.13^{* * *}$ & $148.48^{* * *}$ & $76.08^{* * *}$ & $156.27^{* * *}$ \\
\hline Pseudo $R^{2}$ & 0.1044 & 0.1089 & 0.1155 & 0.2104 & 0.1209 & 0.1839 \\
\hline
\end{tabular}

Data Source: Sample drawn from the SOEP 2000-2005: ${ }^{* * *}$ significant at $1 \%$ level; ${ }^{* *}$ significant at $5 \%$ level; * significant at $10 \%$ level. In all models we control for year effects. 
Table 5: Wage Sample - Descriptive Statistics

\begin{tabular}{|c|c|c|c|c|}
\hline & \multicolumn{2}{|c|}{ Males } & \multicolumn{2}{|c|}{ Females } \\
\hline & Dropouts & $\begin{array}{l}\text { Non- } \\
\text { dropouts }\end{array}$ & Dropouts & $\begin{array}{l}\text { Non- } \\
\text { dropouts }\end{array}$ \\
\hline Hourly Wage & 12.91 & 15.68 & 9.76 & 12.08 \\
\hline Age & 36.87 & 38.87 & 39.10 & 38.64 \\
\hline Migration background & 0.36 & 0.15 & 0.28 & 0.13 \\
\hline Rotter index & 44.90 & 46.70 & 43.75 & 46.37 \\
\hline Prof. Internet Use & 0.18 & 0.43 & 0.15 & 0.34 \\
\hline Armed Forces & 0.01 & 0.01 & 0.00 & 0.00 \\
\hline $\begin{array}{l}\text { Legislators, Senior Officials, } \\
\text { Managers }\end{array}$ & 0.05 & 0.07 & 0.02 & 0.03 \\
\hline Professionals & 0.02 & 0.21 & 0.01 & 0.17 \\
\hline $\begin{array}{l}\text { Technicians and Associate Pro- } \\
\text { fessionals }\end{array}$ & 0.09 & 0.20 & 0.18 & 0.33 \\
\hline Clerks & 0.07 & 0.08 & 0.17 & 0.20 \\
\hline $\begin{array}{l}\text { Service Workers, Shop and Sales } \\
\text { Workers }\end{array}$ & 0.05 & 0.04 & 0.25 & 0.17 \\
\hline $\begin{array}{l}\text { Skilled Agricultural and Fishery } \\
\text { Workers }\end{array}$ & 0.02 & 0.01 & 0.01 & 0.01 \\
\hline $\begin{array}{l}\text { Craft and Related Trades Work- } \\
\text { ers }\end{array}$ & 0.30 & 0.25 & 0.05 & 0.02 \\
\hline $\begin{array}{l}\text { Plant and Machine Operators } \\
\text { and Assemblers }\end{array}$ & 0.30 & 0.10 & 0.11 & 0.02 \\
\hline Elementary Occupations & 0.10 & 0.03 & 0.19 & 0.05 \\
\hline $\mathrm{N}$ & 1,482 & 11,326 & 1,528 & 8,815 \\
\hline
\end{tabular}

Data Source: Sample drawn from the SOEP 2000-2006. Own calculation. 
Table 6: Unemployment Regression, Males

\begin{tabular}{lllll}
\hline \hline & \multicolumn{4}{l}{ Dependent variable: probability of being unemployed } \\
& Marginal effects based on probit estimations \\
& spec. 1 & spec. 2 & spec. 3 & spec. 4 \\
\hline Dropout & $0.111^{* * *}$ & $0.065^{* * *}$ & $0.053^{* * *}$ & 0.044 \\
Age & -0.002 & -0.005 & -.004 & -0.004 \\
Age squared & 0.000 & 0.000 & 0.000 & 0.000 \\
Birth cohorts & yes & yes & yes & yes \\
Year effects & - & yes & yes & yes \\
Migration & - & $0.029^{* * *}$ & $0.022^{* * *}$ & $0.022^{* * *}$ \\
Educational degrees & - & yes & yes & yes \\
Rotter index & - & - & $-0.003^{* * *}$ & $-0.003^{* * *}$ \\
\hline Interaction dropout with... & & - & - & 0.000 \\
migration background & - & - & - & 0.000 \\
Rotter index & - & 22,587 & 22,587 & 22,587 \\
\hline N & 22,587 & - & & \\
\hline \hline
\end{tabular}

Data Source: Sample drawn from the SOEP 2000-2006. Marginal Effects; Standard errors:*** ${ }^{*}$ significant at $1 \%$ level; ${ }^{* *}$ significant at $5 \%$ level; * significant at $10 \%$ level. Standard errors are clustered on an individual level.

Table 7: Unemployment Regression, Females

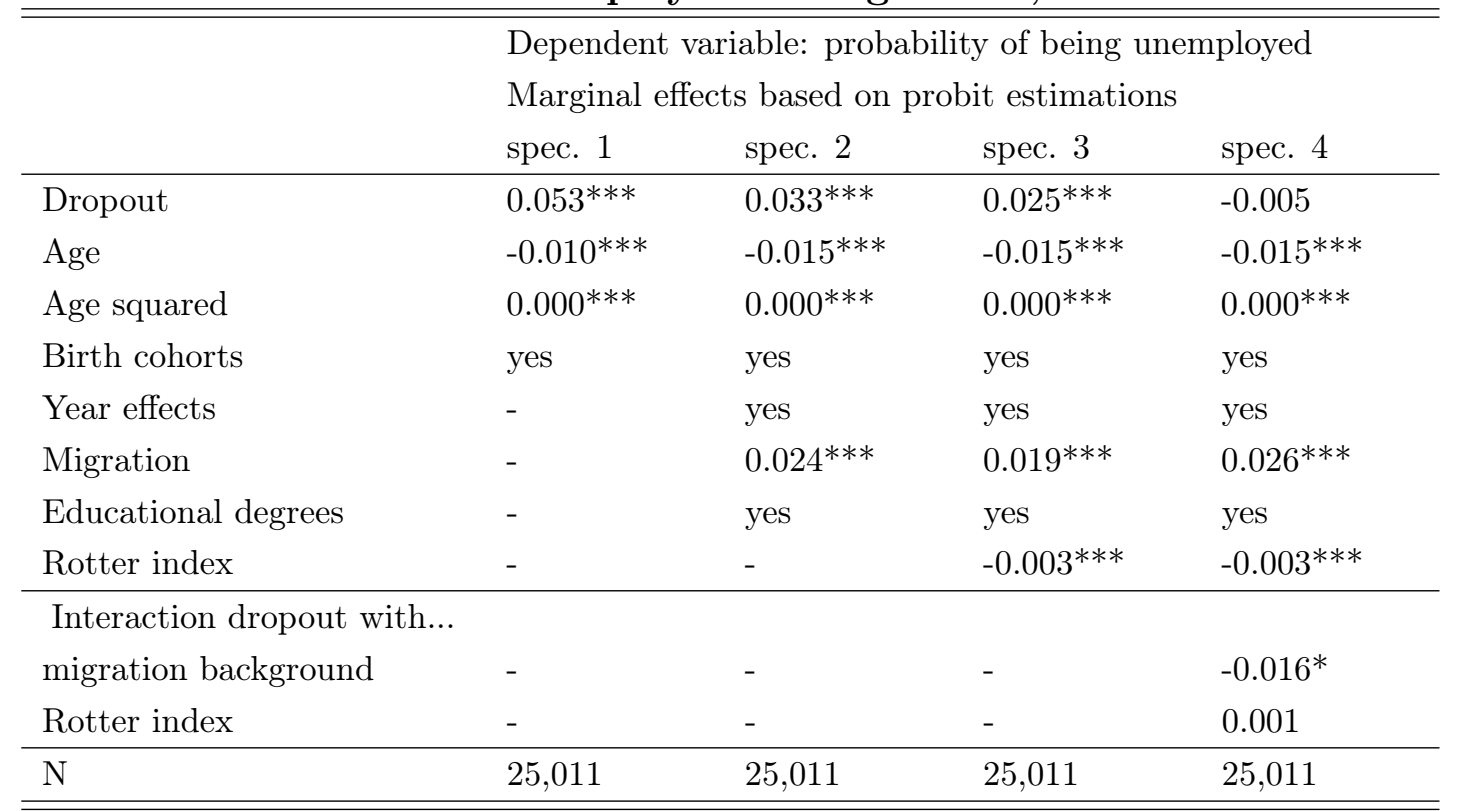

Data Source: Sample drawn from the SOEP 2000-2006. Marginal Effects; Standard errors:***significant at $1 \%$ level; ${ }^{* *}$ significant at $5 \%$ level; ${ }^{*}$ significant at $10 \%$ level. Standard errors are clustered on an individual level. 
Table 8: Wage Regression (OLS), Males

\begin{tabular}{|c|c|c|c|c|c|c|}
\hline & \multicolumn{6}{|c|}{ Dependent variable: log hourly wage } \\
\hline & spec. 1 & spec. 2 & spec. 3 & spec. 4 & spec. 5 & spec. 6 \\
\hline Dropout & $-0.152^{* * *}$ & $-0.061^{* * *}$ & -0.020 & -0.016 & -0.016 & -0.017 \\
\hline Age & $0.086^{* * *}$ & $0.068 * * *$ & $0.070 * * *$ & $0.071^{* * *}$ & $0.072^{* * *}$ & $0.072^{* * *}$ \\
\hline Age squared & $-0.001^{* * *}$ & $-0.001^{* * *}$ & $-0.001^{* * *}$ & $-0.001^{* * *}$ & $-0.001^{* * *}$ & $-0.001^{* * *}$ \\
\hline Birth cohorts & yes & yes & yes & yes & yes & yes \\
\hline Year effects & - & yes & yes & yes & yes & yes \\
\hline Migration & - & $-0.047^{* * *}$ & -0.021 & -0.016 & -0.009 & $-0.029 *$ \\
\hline Educational degrees & - & yes & yes & yes & yes & yes \\
\hline 20-199 employees & - & - & $0.092^{* * *}$ & $0.092^{* * *}$ & $0.095^{* * *}$ & $0.096^{* * *}$ \\
\hline 200-1999 employees & - & - & $0.170^{* * *}$ & $0.172^{* * *}$ & $0.174^{* * *}$ & $0.174^{* * *}$ \\
\hline $\begin{array}{l}\text { More than } 2000 \text { em- } \\
\text { ployees }\end{array}$ & - & - & $0.226^{* * *}$ & $0.225^{* * *}$ & $0.225^{* * *}$ & $0.225^{* * *}$ \\
\hline Industry dummies & - & - & yes & yes & yes & yes \\
\hline Technicians/Associates & - & - & $0.077^{* * *}$ & $0.073^{* * *}$ & $0.065^{* * *}$ & $0.064^{* * *}$ \\
\hline Service Workers & - & - & $-0.111^{* * *}$ & $-0.116^{* * *}$ & $-0.103^{* * *}$ & $-0.103^{* * *}$ \\
\hline Agricultural & - & - & $-0.272^{* * *}$ & $-0.285^{* * *}$ & $-0.268^{* * *}$ & $-0.270^{* * *}$ \\
\hline Craft Workers & - & - & $-0.050^{* *}$ & $-0.048^{* *}$ & -0.026 & -0.027 \\
\hline Plant Operators & - & - & $-0.129^{* * *}$ & $-0.129 * * *$ & $-0.102^{* * *}$ & $-0.101^{* * *}$ \\
\hline Elementary & - & - & $-0.214^{* * *}$ & $-0.212^{* * *}$ & $-0.183^{* * *}$ & $-0.184^{* * *}$ \\
\hline Other occupations & - & - & yes & yes & yes & yes \\
\hline Rotter index & - & - & - & $0.005^{* * *}$ & $0.004^{* * *}$ & $0.004^{* * *}$ \\
\hline Prof. Internet use & - & - & - & - & $0.087^{* * *}$ & $0.085^{* * *}$ \\
\hline \multicolumn{7}{|c|}{ Interaction dropout with... } \\
\hline $\begin{array}{l}\text { migration } \quad \text { back- } \\
\text { ground }\end{array}$ & - & - & - & - & - & $0.107^{* * *}$ \\
\hline Rotter index & - & - & - & - & - & -0.001 \\
\hline prof. internet use & - & - & - & - & - & -0.030 \\
\hline cons & $0.766^{* * *}$ & $1.046^{* * *}$ & $0.880^{* * *}$ & $0.655^{* * *}$ & $0.629 * * *$ & $0.644^{* * *}$ \\
\hline $\mathrm{N}$ & 12,808 & 12,808 & 12,808 & 12,808 & 12,808 & 12,808 \\
\hline$R^{2}$ & 0.108 & 0.224 & 0.380 & 0.386 & 0.394 & 0.396 \\
\hline
\end{tabular}

Data Source: Sample drawn from the SOEP 2000-2006. Standard errors:***significant at 1\% level; **significant at $5 \%$ level; $*$ significant at $10 \%$ level. Standard errors are clustered on an individual level. 
Table 9: Wage Regression (OLS), Females

\begin{tabular}{|c|c|c|c|c|c|c|}
\hline & \multicolumn{6}{|c|}{ Dependent variable: log hourly wage } \\
\hline & spec. 1 & spec. 2 & spec. 3 & spec. 4 & spec. 5 & spec. 6 \\
\hline Dropout & $-0.216^{* * *}$ & $-0.112^{* * *}$ & $-0.046^{* *}$ & $-0.041^{* *}$ & $-0.041^{* *}$ & -0.039 \\
\hline Age & $0.045^{* * *}$ & $0.034^{* *}$ & $0.044^{* * *}$ & $0.043^{* * *}$ & $0.044^{* * *}$ & $0.044^{* * *}$ \\
\hline Age squared & $-0.001^{* * *}$ & $-0.000^{* *}$ & $-0.000 * * *$ & $-0.000 * * *$ & $-0.000 * * *$ & $-0.000^{* * *}$ \\
\hline Birth cohorts & yes & yes & yes & yes & yes & yes \\
\hline Year effects & - & yes & yes & yes & yes & yes \\
\hline Migration & - & $-0.081^{* * *}$ & -0.022 & -0.015 & -0.009 & -0.013 \\
\hline Educational degrees & - & yes & yes & yes & yes & yes \\
\hline 20-199 employees & - & - & $0.124^{* * *}$ & $0.126^{* * *}$ & $0.127^{* * *}$ & $0.128^{* * *}$ \\
\hline 200-1999 employees & - & - & $0.206^{* * *}$ & $0.206^{* * *}$ & $0.207^{* * *}$ & $0.207^{* * *}$ \\
\hline $\begin{array}{l}\text { more than } 2000 \text { em- } \\
\text { ployees }\end{array}$ & - & - & $0.247^{* * *}$ & $0.248^{* * *}$ & $0.249^{* * *}$ & $0.249^{* * *}$ \\
\hline industry dummies & - & - & yes & yes & yes & yes \\
\hline Technicians/Associates & - & - & $0.090^{* * *}$ & $0.089^{* * *}$ & $0.091^{* * *}$ & $0.091^{* * *}$ \\
\hline Service Workers & - & - & $-0.143^{* * *}$ & $-0.140 * * *$ & $-0.125^{* * *}$ & $-0.124^{* * *}$ \\
\hline Agricultural & - & - & -0.109 & -0.112 & -0.109 & -0.108 \\
\hline Craft Workers & - & - & $-0.135^{* * *}$ & $-0.133^{* * *}$ & $-0.112^{* * *}$ & $-0.109^{* * *}$ \\
\hline Plant Operators & - & - & $-0.303^{* * *}$ & $-0.299 * * *$ & $-0.278^{* * *}$ & $-0.275^{* * *}$ \\
\hline Elementary & - & - & $-0.287^{* * *}$ & $-0.275^{* * *}$ & $-0.257 * * *$ & $-0.256^{* * *}$ \\
\hline Other occupations & - & - & yes & yes & yes & yes \\
\hline Rotter index & - & - & - & $0.004^{* * *}$ & $0.004^{* * *}$ & $0.004^{* * *}$ \\
\hline Prof. internet use & - & - & - & - & $0.063^{* * *}$ & $0.059^{* * *}$ \\
\hline \multicolumn{7}{|c|}{ Interaction dropout with... } \\
\hline $\begin{array}{l}\text { migration } \quad \text { back- } \\
\text { ground }\end{array}$ & - & - & - & - & - & 0.014 \\
\hline Rotter index & - & - & - & - & - & -0.000 \\
\hline prof. internet use & - & - & - & - & - & 0.037 \\
\hline cons & $1.439 * * *$ & $1.537^{* * *}$ & $1.280 * * *$ & $1.125^{* * *}$ & $1.100 * * *$ & $1.097^{* * *}$ \\
\hline $\mathrm{N}$ & 10,343 & 10,343 & 10,343 & 10,343 & 10,343 & 10,343 \\
\hline$R^{2}$ & 0.039 & 0.134 & 0.362 & 0.365 & 0.369 & 0.369 \\
\hline
\end{tabular}

Data Source: Sample drawn from the SOEP 2000-2006. Standard errors:*** significant at 1\% level; **significant at $5 \%$ level; $*$ significant at $10 \%$ level. Standard errors are clustered on an individual level. 